\title{
IAMJ
}

INTERNATIONAL AYURVEDIC MEDICAL JOURNAL

\section{AN AYURVEDIC REVIEW ON UNRAVELING THE GOLDEN GOODNESS OF HRUDAYAVARANA}

\author{
Savitha P. K ${ }^{1}$, Ritu Kapoor ${ }^{2}$, Manoj Adlakha ${ }^{3}$ \\ ${ }^{1}$ MD scholar, P.G Dept, Agad Tantra Evam Vyavahar Ayuveda, DSRRAU, Jodhpur, Rajasthan, India \\ ${ }^{2}$ Assistant Professor, P. G Dept. Agad Tantra Evam Vyavahar Ayurveda, DSRRAU, Jodhpur Rajasthan, India \\ ${ }^{3}$ Assistant Professor, P. G Dept, Dravya Guna Vinjana, DSRRAU, Jodhpur, Rajasthan, India
}

Corresponding Author: savithacontactjiji@gmail.com

\section{https://doi.org/10.46607/iamj0809052021}

(Published Online: April 2021)

Open Access

(C) International Ayurvedic Medical Journal, India 2021

Article Received: 06/04/2021 - Peer Reviewed: 07/04/2021 - Accepted for Publication: 08/04/2021

D) Check for updates

\begin{abstract}
Ayurveda is the eternal science in which we can dig out all the current scenario of emerging diseases and their remedies. Ayurveda, the science is very vast as an ocean. For the sake of its benefit, it is divided in to eight branches. Agad tantra evam vyavahara ayurveda is one among the eight branches which deals with the concept of toxicity, its treatment, forensic medicine and medical jurisprudence. Ayurveda Samhita well mentioned all the Sthavara (Plant origin), Jangama (Animal origin) and Krithrima (Artificial) visha (poison), its Symptoms and Management. Charaka Samhita mainly adopted the Chaturvimsadi Upakrama (Twenty-four treatment modalities) for the management of Vishas. Hrudayavarana is one among the Twenty-four treatment modalities used as a preventive, curative and emergency management in toxic conditions. Visha having properties opposite to that of ojas, whereas ojas helps to sustain life in the body.
\end{abstract}

Keywords: Chaturvimsadi Upakrama, Hrudayavarana Ojas, Rasayana

\section{INTRODUCTION}

Agadtantra is the branch that deals with the unique concept about Visha and its management. Visha is a substance that cause vishada (sadness) to the world ${ }^{1}$.Visha includes all the Sthavara (vegetable \& mineral) and jangama (animal origin) visha. Visha enters into the body and it imbalances all the normal functions. 
Hrudayavarana is a unique and effective treatment modality mentioned in Charaka Samhita under the heading of chaturvimsadi upakramas. ${ }^{2}$ Hrudayavarana mainly focusing on protection of hrudaya (Heart). Hrudaya is the site of ojas which helps to sustain life in the body. Hrudyavarana treatment mainly include administration of Ghrita (ghee) with Agada yogas (Formulations used in toxicology) as a remedial measure to protect $\mathrm{Hri}_{\text {- }}$ daya.

\section{Aim \& Objectives}

$>$ To explore the importance of Hrudayavarana Chikista.

> To analyse the Hrudayavarana Chikista in emergency and preventive aspect.

\section{Hrudayavarana}

The concept of Hrudayavarana is not only used just for Vishahara Chikista (Antipoison) butalso applied in different treatment aspects. After hrudayavarana, slesma upachaya (Accumulation of kapha dosha) occurs in the body. To eliminate this Kapha accumulation and the residual poison present in the body, Vamana (Emesis) therapy is induced. ${ }^{3}$

\section{Importance of Hrudayavarana}

- Avarana: Avaraodh, Gatinirodh (Cha. chi 28/59)

The meaning Avarana means the protection

- Upakramam Hrudayarakshanam (Cha, chi 23/46)

The treatment used for the protection of hrudaya

\section{- Hrudayavarana vishavegagamanaava-} rodakaramavaranam (Gangadar)

According to Gangadhar Hrudayavarana helps to arrest/slow down the spread of poison into the vital organs. The spreading of poison is similar to "Rakthamanuapi thailaambuvath" (Similar to spreading of oil in water) indicates the fast spreading of Visha in the body. The ten Visha Gunas (qualities) and their functions clarified the fatality of visha and point out the need of Atyayika Chikista (Emergency management). Hrudayavarana treatment modality is used as an emergency management because it helps to slow down the action of visha and thus gives enough time for management. Hence Hrudayavarana treatment is beneficial for all vishas whether it is sthavara, jangama \& Krithrima visha.

\section{Aspects of Hrudayavarana}

Hrudyavarana treatment can be focused in ----

- Preventive Management

- Emergency management.

\section{$\checkmark$ Preventive management}

Hrudayavaranam nityam kuryacha mitramadhyagah (su.ka1/79)

Acharya susruta add on that Hrudyavarana should be done daily in the company of his friends to protect hrudaya.

\section{Satrumadhy Pratishedam(indu)}

Intelligent person should take Hrudyavarana yogas daily to protect hrudaya.

\section{$\checkmark$ Emergency management} Adou hrudayam Rakshyam tasyavaranam
pibet.....(Cha.chi)

Charaka clarifies that Hrudyavarana procedure should consider as the first aid treatment, Emergency management

\section{What Is Hrudaya?}

The word Hrudaya is derived from Sanskrit Word as HARAN + DANA+AYANA which means Receiving + Giving away + Moving or maintaining a continuous activity of two earlier functions. The organs doing these functions can be included in the term Hrudaya. Since life is sustained in the body mainly by means of circulation (heart), respiration and nervous system, during toxicity these systems are mainly affected and need to be protected, which can be done by means of Hrudayavarana.

$\checkmark$ Hrudaya is mainly made up of the rasada bhaga (Essence) of Raktha and Kapha in the fourth month of pregnancy. ${ }^{4}$

$\checkmark \quad$ Hrudaya abides ojas ${ }^{5}$ and mana(mind) ${ }^{6}$

$\checkmark$ Hrudaya said to be the seat of Atma, Vyana Vayu, Sadhaka Pitta, Avalambaka Kapha, ${ }^{6}$ and Rasa and Prana Vaha Srotas. ${ }^{7}$

$\checkmark$ Hrudaya is Marma-Vital organ ${ }^{8}$

\section{Visha}

Visha is the substance that produce Vishada and has the ability to destruct the whole world. Visha possess Teekshna (Penetrate), Ushna (Hotpotency), Ruksha 
(Dry), Vishada (Non-unctous), Vyavayi (Spreading all over the body), Asukari (Quick acting), Laghu (Light), Vikasi (Debilitate the tissue), Sookshma (Entering the minute pores), Avyaktha rasa (No taste) and Apaki(Undigestable) properties. ${ }^{9}$ The Visha is mainly classified into Sthavara, Jangama, Krithrima Visha.${ }^{10}$ The pathogenesis of all the Visha is same as that it vitiates the Raktha Dhatu initially, then the Tridoshas and their Asrayas finally it destruct the hrudaya and causes death of the patient. ${ }^{11}$ In the symptoms of toxicity, disarrangement of physiological and psychological changes happens in the body. All the Visha have the properties just opposite to the qualities of Ojas, causes the vitiation of Vatapitta dosha and Sadyopranahara (immediate death)in nature The manifestations of Visha is mentioned in terms of Vegas(Stages).Vega is defined as the transmission of Visha from one dhatu/kala (tissue) to another ${ }^{12}$. The principle of Visha chikista is explained by Charaka samhitha in Vishapratisheda Adhyaya.

\section{Ojas}

Ojas is an important essence which is necessary to maintain health, fight against various diseases and to improve the health status.Ojas is formed from the essence of all the dhatu and it is the bala (Strength) of the body. ${ }^{13}$ Ojas is of two types: Para ojas \& Apara ojas. Para ojas is the one which is responsible for Jeeva Dharana/Chetana Anuvrutti (Maintaining life in the body) and it is situated in hrudaya in Ashtabindhu pramana (Quantity of eight drops). Apara Ojas circulates throughout the body and have a quantity of Ardhanjali pramana. ${ }^{14}$ The Kshaya(depletion) of Para Ojas leads to death and Kshaya of Apara Ojas results in malfunctioning of the body. Because of the aforementioned reasons it is imperative that Ojas should be well preserved to maintain life in the body.

\section{Importance of Ghee}

Ghee by its inherent nature has its specific curative action on Vatapitta dosha. Ghee having Unctuous, Sweetness and Cold properties pacifies Vatapitta dosas. ${ }^{16}$ Ghritha counteract the qualities of Visha by Vatapittahara action. Visha causes Manovikaras (mental disorders) like Mada (Delerium), Apsmara (Epilepsy), Moorcha, (Syncope), Unmada (insanity) and Shareerika vyadhis (Physical ailments) like Jwara (fever), Shosha (Emaciation), whereas Ghee improves Dhi, Budhi, Smrithi (Intellectual factors) and also enhances the essence of Ojas. ${ }^{17} \mathrm{In}$ addition, it is rejuvenating and extensively used in various vishaja conditions. The efficacy of Hrudayavarana drugs along with ghee, so as the use of Ajey ghrita, Amrita Ghrita, plain ghee was mentioned in Classics. Daily consumption of ghee in small quantity will impart the Rasayana (Rejuvenating nature) effect and will also neutralize the residual poison in the body

\section{Hrudayavarana Drugs mentioned in classics}

\begin{tabular}{|l|l|l|l|}
\hline Susruta Samhita & Charaka Samhita & Ashtanga hrudaya $^{\mathbf{1 9}}$ & Ashtanga sangraha $^{\mathbf{2 1}}$ \\
\hline Ajey ghrita & Pakwa ikshu rasa & Ajeyaghrta & Ghee \\
Amrita ghrita & Pakwakaka nishpeedya rasa & Amrutaghrita & Ghee+honey \\
Ghee & Goat asruk & Ghrtha, & Agadayoga+ghee \\
Curd & Bhasma abha & Dadhi & Majja \\
Milk & Mrutjala, & Milk & Gomayarasa \\
Honey & & Madhu & Bhasma ambha \\
Coldwater & Coldwater & Krishnamritjala \\
Mayoora, Nakula, & Mayoora, Nakula, & Panchagavyam \\
Godha, Harina Mamsa & & Hirana, Godha mamsa & Dadhi \\
& or mamsa rasa & Gairika jalam \\
& & Kovidara, arka, sireesha, kadabhi \\
& & & Young goat raktha \\
& & & Vrudha mesha raktha \\
& & & Yoshitha varaha raktha \\
\hline
\end{tabular}


Demulsents: Demulcents are substances which form protective coating on the gastric mucous membrane ${ }^{22}$. Milk, Curd, Ghee, Kshoudra (Honey), Majja (Bone marrow) acts like demulcents which delay the absorption of Visha in the body. Milk, Ghee pacify the Vatapitta dosha aggravated by the poison and also increases the ojas in the body.

Gairika jala: Gairika has Pittahara, Vishahara properties and thus pacify the effect of Visha.

Ajeyghrita, Amrita ghrita: These Ghritas have contents like Madhuka, Tagara, Kushta, Pratyakpushpi etc helps to pacify the action of Visha (Visha hara). Also, the property of ghee helps to prevent further absorption. Mamsa/Mamsa rasa (Meat soup): All the Mamsa described in this context have Vata mitigating property and impart Balya (Strength) to the body. Whereas Godha Mamsa is Vishahara in nature. Mamsa rasa/Mamsa is guru in nature and difficult to digest and thus slow down the process of absorption of Visha in the body.

Bhasma ambha (Ash water): Acharya detailed the drug ash mixed with water have the property of Hrudyavarana. The ash can be formed from any of the drug which pacify the Vata dosha and Visha. Svarna (Gold) and Tamra (Copper) are Vishahara in nature and therefore their ash also bears Vishahara property.

Rakta of different animals: The intake of Rakta (Blood) increase the Poshana (Nourishment) of raktha which is vitiated already by the effect of Visha and also helps to prevent the Vata Dosa from vitiation.

Cold Water and Krushna mrit jala: These two have Seeta (Cold) in potency, helps to increase Kapha in the body and decrease the Pitta dosha.

\section{DISCUSSION}

when Visha enters into the body, it initially vitiates the Raktha Dhatu and further vitiates all the Dhatus, Tridosha, finally it stays in Hrudaya and cause death. Visha affects Hrudaya which is both Sthana of Ojas and Manas and there by affects life. In emergency management Hrudyavarana is the modality used to slow down the spread of Visha from one Dhatu to other dhatu. It also increases the time duration of Visha to reach the heart. Hrudayavarana agad yogas with
Ghrita or Ghrita alone itself, envelops the heart as a protective covering to save the life. Properties of ghee also have good role in pacifying Vata pitta raktha dosha and has action against both physiological and psychological changes in the body. Not only this Ghrita is also Ojovardhaka (enhancing Ojas) and impart $R a$ sayana effect in the body. In Panchamahabhuta components Visha is Agni (Fire) \& Akasha (Sky) predominant and Vitiates Vatapitta dosa. Whereas Hrudyavarana drugs have Prithvi (Earth) \& Aap (Water) Mahabhuta predominance and have properties just opposite to the properties of Visha having. The Hrudyavarana dugs have Vatapitta mitigating nature. Some of them act as demulcents and some of them are very hard to digest. All the drugs help to prevent further absorption of Visha or decrease the effect of poison in the body and enhances Ojas. Due to easy availability and protective action, Ghee is considered as best amongst all the Hrudyavarana drugs. In the preventive aspect of Hrudaya, Vaghbata considered Ghee as a Nityaupayogi (Substance which can be used daily) Dravya and rated as Hrudya (Benefit to heart) and it imparts a Hrudyavarana effect

\section{CONCLUSION}

Nowadays, we are exposed with many poisons accidently. when a poison is ingested or enter the body, it affects the normal function of the body. In the present era of industrialization, we cannot avoid the exposure with the poison, but with the use of Hrudyavarana drugs in daily routine we can limit that in some extent. Hrudayavarana treatment can be used in preventive, Curative and Emergency Management. In emergency and curative aspects, the drugs mentioned by Acharyas have to used. In preventive aspect, Ghee should be used to reduce the Prabhava of Visha by its protective effect Use of Nityaupayogi drug as Ghrita will be a great steps for the sake of society.

\section{REFERENCES}

1. Acharya Susruta, Susruta Samhita with Dalhana commentary Nibhanda sangraha, Acharya Yadavji Trikamji editor. Varanasi Choukambha Orientalia. Kalpasthana 3/12;2009,p 569 
2. Acharya YT Acharya YT, editor, Ayurveda Dipika commentary of Chakrapanidatta on Charaka Samhita of Agnivesha, chikitsasthana Varanasi Chowkhambha Sanskrit Series, 2013; 23(28): 573-738.

3. Ashtanga samgraha with Sarvanga Sundhara Commentary of Arunadatta and Ayurveda Rasayana commentary of Hemadri. Reprint Varanasi (India): Chaukambha Orientalia: 2005; Uttarasthana, P; 866.

4. Yadavji T. Sushruta, Sushrut Samhita, Sharir sthana, Garbhavyakrana sharir adhyaya, 4/31. 5th ed. Varanasi; Chaukhmbha Sanskrit Sanshthana; 2001:358.

5. 5.Charak Samhita with Charazk Chandrika Hindi commentary, by Dr Brahmanand Tripathi and Dr Ganga Sahay Pandey, Sutra Sthana, Chapter 30, Verse 7, Chaukhamba Surbharti Prakashan:2007. p.560

6. Prof. P. V Sharma, Ashtanga Hrudya with Sarvangasundara commentary of Arunadatta and Ayurvedarasayana commentary of Hemadri, Sutrasthana, Vishapratishedam adhyayam, chapter 35 , verse $6-7$, Varanasi, (India) Chaukhambha Orientalia 2019 edition: 193

7. Prof. Srikanta murht K. R Sushrutha of Susrutha samhitha with Dalhna commentary with English translation, Vol 1, Chaukhambha Vishwabharathi Varanasi Reprint .2010

8. Prof. P. V Sharma, Ashtanga Hrudya with Sarvangasundara commentary of Arunadatta and Ayurvedarasayana commentary of Hemadri, sareerasthana, Marmavinjanam, chapter 4, verse 13, Varanasi, (India) Chaukhambha Orientalia 2019 edition: 410

9. Prof. P. V Sharma, Ashtanga Hrudya with Sarvangasundara commentary of Arunadatta and Ayurvedarasayana commentary of Hemadri, Utharasthana, Vishapratishedam adhyayam, chapter 35 , verse 7 , Varanasi, (India) Chaukhambha Orientalia 2019 edition:202

10. Prof. P. V Sharma, Ashtanga Hrudya with Sarvangasundara commentary of Arunadatta and Ayurvedarasayana commentary of Hemadri, Utharasthana, Vishapratishedam adhyayam, chapter 35, verse 5, Varanasi, (India) Chaukhambha Orientalia 2019 edition:202

11. Paradakara HS, editor, Sarvanga Sundara Vyakhya of Arunadutta and 'Ayurveda Rasayana' of Hemadri on Astanga Hridaya of Vagbhata, Uttara sthana; Varanasi: Chowkhambha Sanskrit Series, 2016; 35(9-10) 903-956

12. Ashtanga samgraha with Sarvanga Sundhara Commentary of Arunadatta and Ayurveda Rasayana commentary of Hemadri. Reprint Varanasi (India): Chaukambha Orientalia: 2005; Uttarasthana.
13. Acharya JT, editor, Reprint ed. Susrutha Samhita with Banumati commentary of Chakrapani Datta, Sootrasthana; Dosha datu mala ksaya vridhi vignaniyam adhyayam: chapter 15 , verse 22 . Varanasi (India): Chaukambha Orientalia,2010;67

14. Paradakara HSS, editor, 9th ed. Ashtanga Hrudaya with Sarvangasundara commentary of Arunadatta and Ayurvedarasayana commentary of Hemadri. sootrasthana; dosadivignaniyam adhyayam: chapter11, verse 37-8. Varanasi (India): Chaukambha Orientalia; 2005; 189190.

15. Susruta Samhita edited by kaviraj Ambikadatta shastri, Sutrasthana chapter 15 verse no.29, Choukhambha Sanskrit sansthan, Varanasi, 2007. p.61

16. 16.Acharya YT Acharya YT, editor, Ayurveda Dipika commentary of Chakrapanidatta on Charaka Samhita of Agnivesha, sutrasthana Varanasi: Chowkhambha Sanskrit Series, 2013; 27(231): 166-738.

17. Acharya YT, editor, Ayurveda Dipika commentary of Chakrapanidatta on Charaka Samhita of Agnivesha, sutrasthana Varanasi: Chowkhambha Sanskrit Series, 2013; 27(231): 166-738.

18. 18.P.V Sharma, editor Acharya YT, Susruta Samhitha, Nibanda Sangraha commentary of Dalhana, Varanasi: Chaukhambha Orientailia2019, Kalpasthna, Chapter 1, verse $79, \mathrm{p} ; 563$

19. Acharya YT Charaka Samhitha with Ayurveda Deepika Commentary of Chakrapanidatta, Reprint ed: Varanasi: Chaukamba Orientalia, 2015; Chikitsa sthana, P; 574.

20. Prof. P.V Sharma, Ashtanga Hrudya with Sarvangasundara commentary of Arunadatta and Ayurvedarasayana commentary of Hemadri, Utharasthana, Vishapratishedam adhyayam, chapter 35 , verse 53-54, Varanasi, (India) Chaukhambha Orientalia 2019 edition:202

21. Ashtanga samgraha with Sarvanga Sundhara Commentary of Arunadatta and Ayurveda Rasayana commentary of Hemadri. Reprint Varanasi (India): Chaukambha Orientalia: 2005; Uttarasthana, P; 866

\section{Source of Support: Nil \\ Conflict of Interest: None Declared}

How to cite this URL: Savitha P. K et al: An Ayurvedic Review On Unraveling The Golden Goodness Of Hrudayavarana. International Ayurvedic Medical Journal \{online\} 2021 \{cited May, 2021\} Available from: http://www.iamj.in/posts/images/upload/995_999.pdf 